\title{
Porosity and Mechanical Properties of Zirconium Ceramics
}

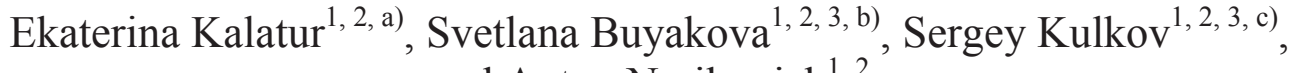 \\ and Anton Narikovich ${ }^{1,2}$ \\ ${ }^{1}$ National Research Tomsk State University, Tomsk, 634050, Russia \\ ${ }^{2}$ Institute of Strength Physics and Materials Science SB RAS, Tomsk, 634055, Russia \\ ${ }^{3}$ National Research Tomsk Polytechnic University, Tomsk, 634050, Russia \\ a) Corresponding author: kalatures@mail.ru \\ b) sbuyakova@ispms.tsc.ru \\ c)kulkov@ispms.tsc.ru
}

\begin{abstract}
The article studies the porous ceramics consisting of ultra-fine $\mathrm{ZrO}_{2}$ powders. The porosity of ceramic samples varied from $15 \%$ to $80 \%$. The structure of the ceramic materials had a cellular configuration. The distinctive feature of all experimentally obtained strain diagrams is their nonlinearity at low deformations characterized by the parabolic law. It was shown that the observed nonlinear elasticity for low deformations shown in strain diagrams is due to the mechanical instability of cellular elements of the ceramic framework.
\end{abstract}

\section{INTRODUCTION}

Porous ceramic materials are successfully used in various fields, including the heat-insulating materials intended for buildings, because of their durability, corrosion resistance and thermal stability [1-3]. The combination of these characteristics is especially important for the construction works in seismic regions.

Ceramics based on partially stabilized zirconia are the most interesting materials among the variety of ceramics due to their inherent transformation toughening. It is known that the characteristics are determined by the quality of initial ceramic powder (particle shape, particle size distribution), compaction conditions and sintering procedure, as well as any properties of each phase contained in them and how these phases (including pores) are arranged in relation to each other. The most important factor in the successful application of the materials is understanding the features of their structure and its influence on their behavior under mechanical impact.

The aim of the paper is to examine the impact of $\mathrm{ZrO}_{2}\left(\mathrm{Me}_{x} \mathrm{O}_{y}\right)$ ceramic pore structure on the peculiarities of their deformation behavior and mechanical properties.

\section{MATERIALS AND EXPERIMENTAL PROCEDURE}

The study employed the ceramics produced from powders of $\mathrm{ZrO}_{2}(\mathrm{MgO}), \mathrm{ZrO}_{2}\left(\mathrm{Y}_{2} \mathrm{O}_{3}\right)$ by liquid-phase decomposition of precursors synthesized in high-frequency discharge plasma (the plasma chemistry method). Porous $\mathrm{ZrO}_{2}(\mathrm{MgO}), \mathrm{ZrO}_{2}\left(\mathrm{Y}_{2} \mathrm{O}_{3}\right)$ ceramic samples were prepared by the compaction of powders and their subsequent sintering at homologous temperatures varying from 0.63 to 0.56 during the isothermal soaking for 1 to 5 hours. The porosity of $\mathrm{ZrO}_{2}(\mathrm{MgO})$ and $\mathrm{ZrO}_{2}\left(\mathrm{Y}_{2} \mathrm{O}_{3}\right)$ ceramics ranged from $15 \%$ to about $45 \%$ and from about $30 \%$ to $80 \%$, respectively. X-ray studies were carried out using a diffractometer with $\mathrm{CuK}_{\alpha}$ source of filtered radiation. The studies on the ceramic structure were carried out using Philips SEM 515 scanning electron microscope. Mechanical tests of the samples of porous ceramics were performed by a uniaxial compression method using Instron-1185 testing system at the constant loading rate of $4 \times 10^{-4} \mathrm{~s}^{-1}$. 


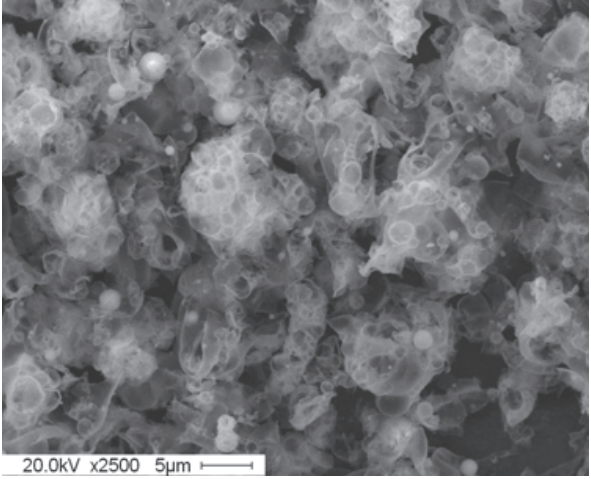

(a)

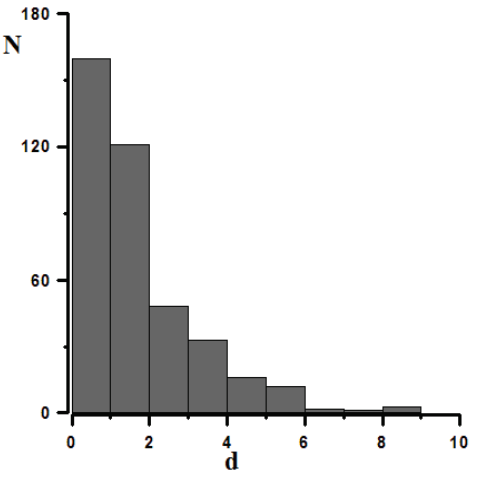

(b)

FIGURE 1. Plasma-chemically synthesized $\mathrm{ZrO}_{2}\left(\mathrm{Y}_{2} \mathrm{O}_{3}\right)$ powder: (a) SEM picture, (b) particle size distribution

\section{RESULTS AND DISCUSSION}

\section{Powders}

Figure 1(a) represents the SEM-image of plasma-chemically synthesized $\mathrm{ZrO}_{2}$ powder $\left(3 \mathrm{~mol} \% \mathrm{Y}_{2} \mathrm{O}_{3}\right)$, while Figure 1(b) depicts the powder particle size distribution. The morphological structure of $\mathrm{ZrO}_{2}(3 \mathrm{~mol} . \% \mathrm{MgO})$ and $\mathrm{ZrO}_{2}\left(3 \mathrm{~mol} . \% \mathrm{Y}_{2} \mathrm{O}_{3}\right)$ powders is practically identical and includes hollow spherical particles and a large number of aggregates having no regular shape. The average size of the particles of spherical $\mathrm{ZrO}_{2}(\mathrm{MgO})$ and $\mathrm{ZrO}_{2}\left(\mathrm{Y}_{2} \mathrm{O}_{3}\right)$ powders was 1.8 and $1.5 \mu \mathrm{m}$, respectively.

The phase composition of $\mathrm{ZrO}_{2}\left(\mathrm{Y}_{2} \mathrm{O}_{3}\right)$ powder includes tetragonal and monoclinic $\mathrm{ZrO}_{2}$. $\mathrm{The}_{\mathrm{ZrO}}(\mathrm{MgO})$ powder comprised the cubic, tetragonal and monoclinic phases of $\mathrm{ZrO}_{2}$. The fraction of tetragonal $\mathrm{ZrO}_{2}$ in $\mathrm{ZrO}_{2}\left(\mathrm{Y}_{2} \mathrm{O}_{3}\right)$ powder amounted about $95 \%$, while that of cubic $\mathrm{ZrO}_{2}$ in $\mathrm{ZrO}_{2}(\mathrm{MgO})$ powder was $75 \%$. The average size of the coherent scattering regions (CSR) of tetragonal $\mathrm{ZrO}_{2}$ in $\mathrm{ZrO}_{2}\left(\mathrm{Y}_{2} \mathrm{O}_{3}\right)$ powder was $20 \mathrm{~nm}$, and for the monoclinic modification it was $50 \mathrm{~nm}$. The average size of CSR for cubic modification of $\mathrm{ZrO}_{2}$ in $\mathrm{ZrO}_{2}(\mathrm{MgO})$ powder was $20 \mathrm{~nm}$, for monoclinic $\mathrm{ZrO}_{2}$ it was $30 \mathrm{~nm}$ and for the tetragonal phase it was $15 \mathrm{~nm}$.

\section{SINTERED CERAMICS}

Figure 2(a) represents the SEM-image of $\mathrm{ZrO}_{2}\left(\mathrm{Y}_{2} \mathrm{O}_{3}\right)$ ceramic structure and the pore size distribution. The structure of $\mathrm{ZrO}_{2}(\mathrm{MgO})$ and $\mathrm{ZrO}_{2}\left(\mathrm{Y}_{2} \mathrm{O}_{3}\right)$ ceramics was represented by a cellular frame. The cells were nearly spherical and the cell size exceeded many-fold the thickness of walls that were represented by a single-layer stack of $\mathrm{ZrO}_{2}$ grains.

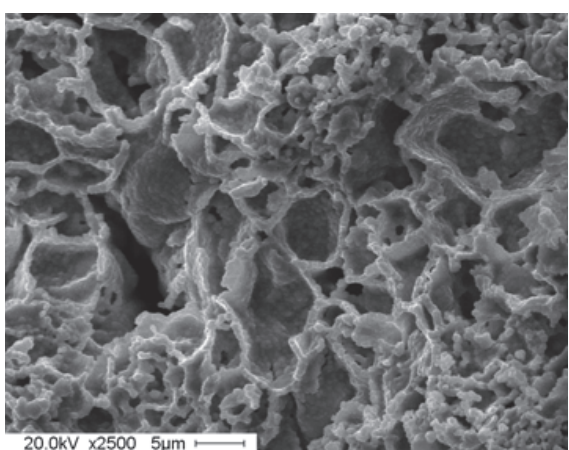

(a)

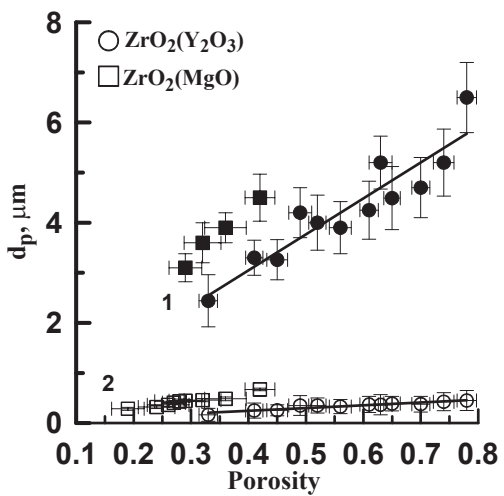

(b)

FIGURE 2. Structure and characteristics of zirconia ceramics: (a) SEM-picture of $\mathrm{ZrO}_{2}\left(\mathrm{Y}_{2} \mathrm{O}_{3}\right)$ ceramics with porosity of about $40 \%$ and (b) dependence of average pore size on porosity 


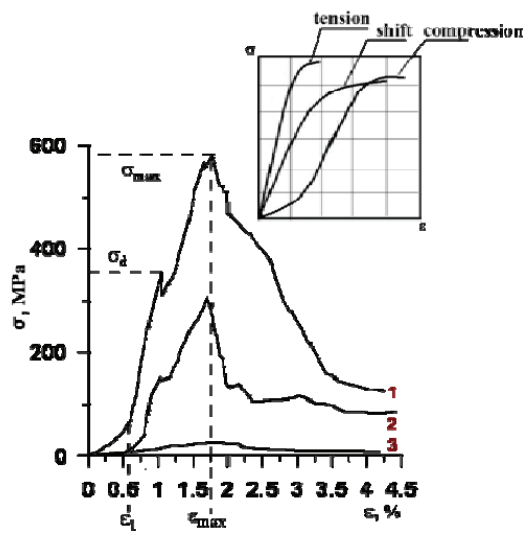

(a)

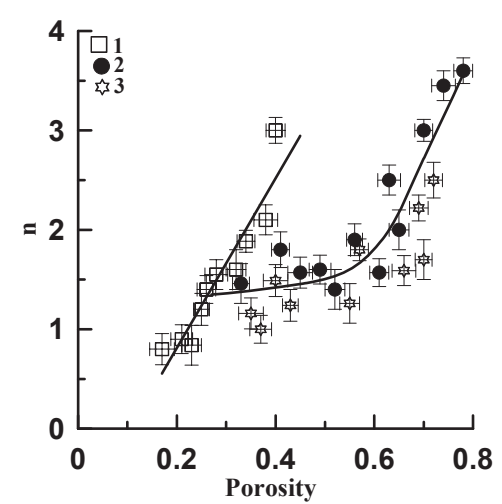

(b)

FIGURE 3. Alteration of parameters of $\mathrm{ZrO}_{2}\left(\mathrm{Me}_{x} \mathrm{O}_{y}\right)$ porous ceramics. a) stress-strain diagrams of $\mathrm{ZrO}_{2}\left(\mathrm{Me}_{x} \mathrm{O}_{y}\right)$ porous ceramics compression, b) dependence of exponent $n$ on $\mathrm{ZrO}_{2}\left(\mathrm{Me}_{x} \mathrm{O}_{y}\right)$ ceramics porosity. Inset: stress-strain diagrams of high porous foams with cellular structure under different types of loading. $1-\mathrm{ZrO}_{2}(\mathrm{MgO})$ ceramics with bimodal pore size distribution; 2 -

$\mathrm{ZrO}_{2}\left(\mathrm{Y}_{2} \mathrm{O}_{3}\right)$ ceramics with bimodal pore size distribution; $3-\mathrm{ZrO}_{2}\left(\mathrm{Y}_{2} \mathrm{O}_{3}\right)$ ceramics with unimodal pore size distribution

The pore size distribution was bimodal. The first maximum was formed by equiparticle pores, the voids that were not filled with powder particles during the compaction, and the second maximum was conditioned by the larger pores with a shape close to spherical. The plots presented in Fig. 2(b) demonstrates the dependence of the average size of equiparticle and large spherical pores on the porosity in $\mathrm{ZrO}_{2}(\mathrm{MgO})$ and $\mathrm{ZrO}_{2}\left(\mathrm{Y}_{2} \mathrm{O}_{3}\right)$ ceramics. It is clear that the increase of pore volume in the material from about $30 \%$ to $80 \%$ achieved by reducing the sintering temperature of the samples was accompanied by the increase of the average size of large pores from 2 to $6 \mu \mathrm{m}$. Changing the porosity of the material had practically no effect on the average size of equiparticle pores having the average size of $0.5 \mu \mathrm{m}$. It can be assumed that the presence of large pores close to a spherical shape in the ceramics is conditioned by the presence of hollow spherical particles in the source powders, since their average size is commensurate with the average size of large pores occurring in the sintered material.

Figure 3(a) shows the stress-strain diagram during the compressive loading of $\mathrm{ZrO}_{2}\left(\mathrm{Y}_{2} \mathrm{O}_{3}\right)$ and $\mathrm{ZrO} 2(\mathrm{MgO})$ ceramic samples having the porosity exceeding $30 \%$. It is characteristic for these ceramics to have a bimodal pore distribution. The ascending branches of the stress-strain diagrams of porous ceramics (stage of active deformation) can be characterized by two distinctive features: 1) non-Hookean behavior up to reaching the strain value $\varepsilon_{1}, 2$ ) the presence of the vertical sections referring to stress relieving and occurrence of microfractures in the material. The occurrence of the first microfractures in the material was recorded as the first vertical section of the stress relief $\sigma_{\mathrm{d}}$. Despite the appearance of separate material failures that had a local character, the macro-volume of loaded sample retained the ability to resist the increasing load up to the stress value $\sigma_{\max }$ that corresponds to the ultimate strain $\varepsilon_{\max }$.

Such $\sigma-\varepsilon$ form of diagrams are also characteristic for materials that have a rod or cellular structure. The authors of the study [4] have shown that on the compression loading of $\mathrm{ZrO}_{2}$ porous ceramics having the structure represented by a ceramic framework consisting of randomly oriented rod elements, there is a reversible loss of the mechanical stability of the rod elements (micromechanical instability [5]), which leads to the occurrence of nonlinear connection between stress and strain during the elastic strain of the material.

In Fig. 3(a) the inset [6] represents a stress-strain curve of highly porous foams with a cellular structure for different types of loading. It can be seen that the form of strain diagrams $\sigma-\varepsilon$ during the compression of foams is similar to that of $\mathrm{ZrO}_{2}\left(\mathrm{Y}_{2} \mathrm{O}_{3}\right)$ and $\mathrm{ZrO}_{2}(\mathrm{MgO})$ porous ceramics obtained in this work. Loading of studied $\mathrm{ZrO}_{2}\left(\mathrm{Y}_{2} \mathrm{O}_{3}\right)$ and $\mathrm{ZrO}_{2}(\mathrm{MgO})$ porous ceramics in the load-relief mode at the initial section up to strain values $\varepsilon_{1}$ revealed no residual deformation, which indicates that the elastic nature of the ceramics deformation conditioned by the reversible loss of the cellular element stability. Restructuring the $\sigma-\varepsilon$ diagrams of $\mathrm{ZrO}_{2}\left(\mathrm{Y}_{2} \mathrm{O}_{3}\right)$ and $\mathrm{ZrO} 2(\mathrm{MgO})$ porous ceramics in double logarithmic coordinates allows determining the value of the exponent $n$ in the equation of strain $\left(\sigma=K \varepsilon^{n}\right)$ using the experimental data.

Figure 3(b) shows the dependence of the exponent $n$ from the equation of strain on the porosity of $\mathrm{ZrO}_{2}\left(\mathrm{Me}_{x} \mathrm{O}_{y}\right)$ ceramics. It is evident that the index is increasing with the growth of the porosity of both systems. However, for the porosity varying from $30 \%$ to $50 \%$ the value of the exponent $\mathrm{n}$ is changes negligibly and averages 1.3 . 


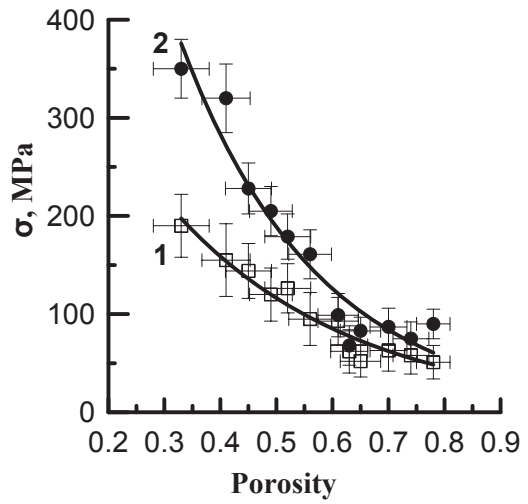

FIGURE 4. $\mathrm{ZrO}_{2}\left(\mathrm{Y}_{2} \mathrm{O}_{3}\right)$ ceramics porosity effect: stress $\sigma_{1}$ that causes initial microfractures (1), ultimate strength $\sigma_{\max }(2)$

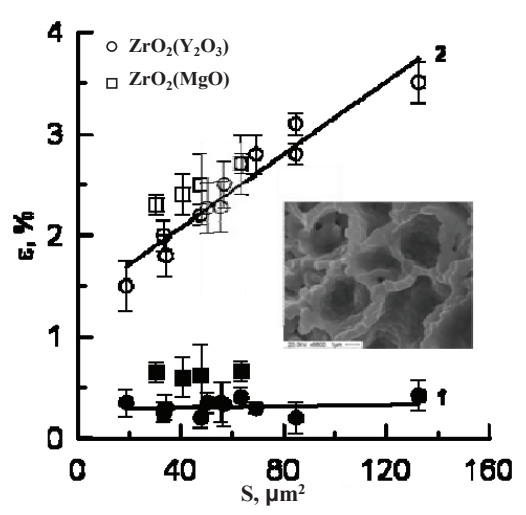

FIGURE 5. Effect of surface area of $\mathrm{ZrO}_{2}\left(\mathrm{Me}_{x} \mathrm{O}_{y}\right)$ ceramics pores: strain $\varepsilon_{1}(1)$, ultimate strain $\varepsilon_{\max }(2)$

Figure 4 represents the stress $\sigma_{1}$ that causes initial microfractures (1) and the ultimate strength $\sigma_{\max }(2)$ depending on the porosity of $\mathrm{ZrO}_{2}\left(\mathrm{Y}_{2} \mathrm{O}_{3}\right)$ ceramics. Increasing the porosity of $\mathrm{ZrO}_{2}\left(\mathrm{Y}_{2} \mathrm{O}_{3}\right)$ ceramics with a bimodal distribution of pore size from about $30 \%$ to $80 \%$ lead to the decrease of $\sigma_{\mathrm{d}}$ value from about 200 to $50 \mathrm{MPa}$ and drop of the tensile strength $\sigma_{\max }$ from about 400 to $100 \mathrm{MPa}$. With increasing porosity, the difference between the amount of stress $\sigma_{\mathrm{d}}$ that causes the first microfractures and the ultimate strength $\sigma_{\max }$ was reducing, which indicates that the occurrence of microfractures leads to the destruction of material as a whole. Dependencies of ultimate strength $\sigma_{\max }$ and stress $\sigma_{\mathrm{d}}$ that causes initial microfractures in $\mathrm{ZrO}_{2}(\mathrm{MgO})$ porous ceramics on the porosity have a similar form: the increase of the porosity from about $15 \%$ to $45 \%$ resulted in a decrease of $\sigma_{\mathrm{d}}$ value from about 800 to $100 \mathrm{MPa}$ and $\sigma_{\max }$ from 1200 to approximately $200 \mathrm{MPa}$.

Figure 5 shows the dependencies of strain $\varepsilon_{1}(1)$ and ultimate strain $\varepsilon_{\max }$ that corresponds to the ultimate strength (2) on the surface area of pores in $\mathrm{ZrO}_{2}\left(\mathrm{Me}_{x} \mathrm{O}_{y}\right)$ ceramics with the bimodal pore size distribution.

The surface area of pores was calculated on the assumption of their sphericity. Increasing the pore surface area lead to the increase of the ultimate strain to approximately $3.5 \%$. The dependence of strain that corresponds to the mechanical instability of cellular elements on the surface area of pores was different. The increase of the surface area of pores in ceramics had virtually no impact on the amount of strain $\varepsilon_{1}$, which averaged $0.5 \%$.

\section{CONCLUSIONS}

It was elucidated that the structure of $\mathrm{ZrO}_{2}\left(\mathrm{Me}_{x} \mathrm{O}_{y}\right)$ ceramics made of powders consisting of hollow spherical particles with the porosity of $30 \%$ is represented by a cellular framework with the bimodal porosity, formed by large pores with the shape close to spherical and pores that were not filled with the powder particles during the compaction. It was found that $\mathrm{ZrO}_{2}\left(\mathrm{Me}_{x} \mathrm{O}_{y}\right)$ ceramics with bimodal pore size distribution at the porosity exceeding $30 \%$ demonstrate the micromechanical instability during the compaction, which is caused by the reversible deformation of the cellular elements. For the cases of such ceramics the increase of pore volume is accompanied by the increase of strain in the elastic area.

This work was partially supported in the frame of Agreement No. 14.575.21.0040.

\section{REFERENCES}

1. Yu. Selivanov and E. Loginova, Stroit. Mater. 7, 49 (2010).

2. L. A. Gomze and L. N. Gomze, IOP Conf. Ser. Mater. Sci. Eng. 47 (2013).

3. L. A. Gomze and L. N. Gomze, Epitoanyag 3, 102 (2008).

4. S. Kulkov, V. Maslovskii, and S. Buyakova, Tech. Phys. Russ. J. Appl. Phys. 47(3), 320 (2002).

5. E. Kalatur, A. Kozlova, S. Buyakova, and S. Kulkov, IOP Conf. Ser. Mater. Sci. Eng. 47 (2013).

6. A. Dement'ev, Mech. Polymers 4, 594 (1970). 